\title{
ADMINISTRATIVE CAPACITY BUILDING NEEDS OF PRINCIPALS FOR EFFECTIVE MANAGEMENT OF PUBLIC SECONDARY SCHOOLS IN ENUGU STATE, NIGERIA
}

\section{LAMBERT K. EJIONUEME*, DENIS C. AGBO, FRANCES A. ALIMIGBE, M. WALI, CLIFFORD E. OGHENEAKOKE}

Educational Foundations, University of Nigeria, Nsukka

Department of Social Sciences Education, Delta State University Abraka Delta State, Nigeria

\begin{abstract}
This study was on the administrative capacity building needs of principals of public secondary schools in Enugu state, Nigeria. The study was guided by three research questions and two null hypotheses. Descriptive survey design was adopted for the study. The population of the study was 834, comprising of 278 principals and 556 vice principals in the 278 public secondary schools in Enugu state. The entire population was used for the study because of the manageable size of the population. There was therefore no sampling of the population. The instrument used for data collection was a 24 - item questionnaire titled Questionnaire on Administrative Capacity Building Needs of Principals (QACBNP). Mean scores and standard deviations were used in answering the research questions, while the z-test statistics was used in testing the hypotheses at 0.05 level of significance. The findings indicated that the principals need administrative capacity building in student personnel administration, financial administration and school-community relations administration. Based on the findings, the researchers recommended that principals and vice principals should be exposed to regular conferences, seminars, and workshops on administrative proficiency, that teacher educational institutions should include administrative skills of school administrators in their curriculum, and that workshops and seminars should be organized for newly appointed principals in administrative proficiency needed by principals for effective school administration.

KEYWORDS: Capacity, Capacity Building, Capacity Building Needs, Principals, Effective Management, Public Secondary Schools
\end{abstract}

Received: Jun 08, 2020; Accepted: Jun 28, 2020; Published: Sep 28, 2020; Paper Id.: IJMPERDJUN20201455

\section{INTRODUCTION}

The effectiveness of any organization, educational institutions inclusive, depends on those who plan and supervise those who execute the plan to achieve set goals. The headship of secondary schools is a position which coffers on the heads the power and authority to both lead in the planning and in the supervision of those who execute the plan to achieve set goals. The way principals go about the execution of the functions conferred on them by their positions is therefore very vital in the achievement of secondary education objectives. In other words, the quality of the principals' leadership is very important in the achievement of secondary education objectives. The leadership role of school heads is a major factor in promoting the schools' all-round performance, in improving students' growth and discipline, and in improving teachers' development and productivity (Igwe, 2006). 
It must be noted that effective leadership qualities of school heads are not inherent in either the person occupying the position nor the position of authority, rather it is acquired or developed through systematic training. Farley (2003) observed that in order to contend with the new demands and challenges of increased exposition and technological advancement in the world, the school head must acquire a repertoire of competence. Akubue (1985) pointed out that unprepared personnel charged with administrative responsibilities may be familiar with the administrative position, but not necessarily competent for the position. Arubayi (2004) opined that training in proficiency is necessary because if proficiencies acquired through such training are properly applied, the educational objectives could be better realized. Therefore to be effective in the discharge of their duties, principals are expected to acquire relevant proficiencies and competencies both from outside and on-the-job. These proficiencies include those needed in managing all facets of the school.

\section{Conceptual Framework}

Secondary school principals are supposed to be leaders of their schools, that is, they are supposed to influence their staff and students to carry out their responsibilities in order to achieve institutional objectives. The extent to which principals achieve these objectives depends not only on the caliber of staff and quality of students but also on the principals' training and experience. A principal is said to be effective when he/she is able to make his/her staff and students do what are expected of them. To lead up to expectations demands that the principals should possess some proficiencies that will enable them function effectively in the position.

Capacity refers to the ability to perform an activity expertly. It connotes an established habit of doing things and involves possession of professional capabil[ity through both formal and informal training (Osinem \& Nwoji, 2005). Capacity in this study refers to the proficiencies, knowledge and attitude resulting from training which secondary school principals apply in the course of coordinating the human and material resources in their schools for the achievement of secondary education objectives.

School heads and others who are in positions of leadership need capacity in order to be effective. Omsteal (2008) opined that school heads should acquire dexterity and proficiency such as ability to co-ordinate functions, activities, interest and assignment, ability to provide sense of security to staff and students, ability to maintain some measure of stability and flexibility among staff, ability to involve staff in planning and decision making. Eleanor (2001) identified the proficiencies needed in staff personnel administration to include: ability to recruit needed qualified staff, ability to prepare job description and schedule of duties, ability to carry out regular supervision, ability to maintain discipline among staff, ability to plan and carry out orientation for new staff, and ability to encourage staff to attend professional development programmes, ability to organize staff meetings, ability to delegate responsibilities, and ability to involve staff in decisionmaking. Nwandu, Ani and Agbo (1999) opined that administrative proficiencies required in human resource management include: planning for manpower needs, planning for future balance in manpower requirements, and planning for recruiting and selecting personnel. Farrant (2002) observed that school administrators need ability to encourage students to play a role in school administration and ability to delegate responsibilities to student. Others are proficiencies like providing opportunities for students to develop responsibly, ability to ensure effective implementation of good instructional programme and ability to ensure that teaching and learning takes place.

These proficiencies and dexterities are acquired through training (including mentorship) and experience and they equip the individuals with knowledge to perform effectively. Development of such proficiencies refers to the process of 
equipping the personnel with the understanding, skills and access to information, knowledge and training. It focuses on a series of actions aimed at helping the individuals to increase the knowledge, proficiencies and understanding already possessed and to develop the attitude needed to bring about desired professional change in them (United Nations Development Programme (UNDP), (1999).

Administrative capacity building in this study refers to efforts geared towards improving the level of knowledge, skills, attitudes, values and attitudes possessed by secondary school principals for their effectiveness in the administration of secondary schools. It connotes training given to principals in order to increase their proficiencies, capability, knowledge, aptitude and attitude for effective performance of their functions as school administrators. It is also called professional skills development.

Administration is the ability to make people, and things function so that set objectives will be achieved. It involves directing and controlling the affairs of an organization. It is the art of organizing the human and material resources available to an organization for the purpose of achieving organizational objectives. According to Ogbonnaya (2004), it is the coordination of human and material resources towards the attainment of some predetermined objectives. Peretemode (1996) sees administration as performance of executive duties, the carrying out of the policies and decisions to fulfill a purpose, and the controlling of the day-to-day running of an organization.

Educational administration is the process through which manpower, funds and instructional materials are harnessed for the attainment of educational goals (Ochai, 2012). It is the planning, organization, coordination and control of human financial and material resources available to education towards the attainment of educational objectives. According to Ochai, the concern of the school administrator or school head is to direct the efforts of staff and students in the school towards the achievement of school goals. Ochai further noted that for the school heads to effectively harness the manpower, funds and material resources they require professional proficiencies which needs continual development or updating.

Administrative capacity building refers to planned activities concerned with increasing and enlarging the capabilities of employees to enable them handle higher responsibilities (Peretomode, 2007). Administrative capacity building is geared towards improving upon workers' performance in order to achieve organizational objectives more efficiently. Administrative capacity building can take different forms such as seminars, symposia, workshops, conferences, exhibitions, in-service training programme, among others and the duration varies from hours, days, weeks, months to years (Ogunsaju, 2006). Capacity building leads to improvement of the professional competence and productivity of the recipients. The school principals therefore need capacity building to function effectively, and efficiently in the pursuit of schools' objectives. Federal Republic of Nigeria (2014) noted that head teaches should acquire a repertoire of relevant proficiences and competencies in planning all facets of school administration such as staff personnel administration, school-community relations administration, curriculum administration, student personnel administration and financial administration. The pre-service teacher education is never adequate for the principals to perform their administrative functions effectively and efficiently. Administrative capacity building serves as opportunity to complement the principals' administrative effectiveness in secondary schools.

Capacity building is imperative for effective performance of principals. According to Alozie (1997) professional proficiencies development for principals is expected to embrace the extension of knowledge in subject and content areas, facilitation of adaptation to work, improvement of interpersonal competency, fostering the mastery of integrating theory 
with practice, development of proficiencies in implementing changes, improvement of ability in using various teaching techniques, and the development of awareness of individual differences. This is so because the principals wear many hats being manager, administrator, instructional and curriculum leader public relations officer, financial administrator, welfare officer, among others, at different points in a day. A principal is a leader of learning communities where staff members meet on regular basis to discuss their work, work together to solve problems, reflect on their jobs, and take responsibility for what student acquire in terms of knowledge, skills, values, and attitudes. Blase and Blase (2001) expressed the duties of the principals in specific behavior such as making suggestions, giving feedback, modeling effective instruction, soliciting opinions, supporting collaborations, providing professional development opportunities, and giving praise for effectiveness and efficiency. Chang (n.d) observed that a principal is expected to know or understand: what goes on in every classroom, curriculum development standards, all members of his/her staff, staff's strength and areas of development, learning activities so as to produce desired learner outcomes, supervision models, and political dynamics in the community. The principals therefore are expected to possess knowledge and skills to function effectively within the context of a set of beliefs or values. According to Agbo (2014), a principal needs some professional proficiencies in order to facilitate; coordinate; be empathic, be visionary; take risks; establish good working relationship with staff; plan and coordinate curriculum, social and cultural diversity; support teachers in providing quality education for all students, nurture cooperation between the staff and the communities they serve; and to assess the needs and strengths of the school and the community. These are meant to give synaric effect in the school and link the work efforts of staff to the schools' purpose.

\section{Statement of the Problem}

From what is observable among the principals and what happen in secondary schools, especially in Enugu state, it appears that the principals do not possess adequate proficiencies for effective school administration. Among pointers to this are: lack of visionary leadership, poor policy implementation, poor financial management, poor quality of products. Others are indiscipline among staff and students, poor maintenance culture, poor leadership style, various kinds of conflicts, hostile school climate, lack of staff development programme, poor relationship with host communities, among others. In specific terms, it is observed that most of the students come to school late just as many of them are truants and absent themselves from school often. The teachers and even the principals seldom attend seminars, workshops, and conferences. Many of the principals do not come to school regularly and do not command respect from their staff and students. Many of them do not have vision and mission and therefore do not improve their schools rather they work the schools down.

The picture painted above has many educational implications, among which are: poor performance of students, high rate of job dissatisfaction among staff, poor school environment, low achievement of secondary education objectives, conflicts, among others. This calls for provision of opportunities for the principals to grow in administrative proficiencies on the job in order to be effective and efficient, especially through the application of modern management techniques and skills. This calls for principals' administrative capacity building which should be based on proficiency needs of their office. This informs the researchers' interest in carrying out this study.

\section{Purpose of the Study}

The purpose of the study is to investigate the capacity building needs of principals for effective management of public secondary schools in Enugu state. The study determined

- The administrative capacity building needs of principals in student personnel management 
- The administrative capacity building needs of principals in financial management

- The administrative capacity building needs of principals in school-community relations management

\section{Research Questions}

Three research questions guided the study

- What are the administrative capacity building needs of secondary school principals in student personnel administration

- What are the administrative capacity building needs of secondary school principals in financial administration

- What are the administrative capacity building needs of secondary school principals in school-community relations administration

\section{Hypotheses}

Two null hypotheses tested at 0.05 level of significance guided the study

- There is no significant difference between the mean responses of principals and vice-principals in public secondary schools in Enugu state on the professional administrative capacity building needed by principals in student personnel administration.

- There is no significant difference between the mean responses of principals and vice-principals in public secondary schools in Enugu state on the administrative capacity building needed by principals in financial management

\section{Significance of the Study}

In practical terms the findings of this study will be of immense benefit to the state Post Primary Schools Management Board (PPSM B), secondary school principals, teachers, students and the society.

The findings will be beneficial to the PPSMB as it will enlighten the board on the task areas of school administration that the principals require professional skills development. This will inform the board on the need to regularly organize administrative capacity building programme for the retraining of principals for effectiveness and efficiency.

The findings will benefit the principals because they stand to gain when administrative capacity building programmes are organized regularity for them. They will use the knowledge, skills, attitudes and values acquired in the overall improvement of their schools which will benefit the teachers, the students and the society who stand to gain from the products of the secondary schools. The findings of this study will be made known to the expected beneficiaries through seminars and workshops where the findings will be discussed. The beneficiaries of the findings of this study could also access the findings through journal publication.

\section{METHODOLOGY}

Descriptive survey research design was adopted for the study. The population of the study was 834, comprising 278 principals and the 556 vice principals in the 278 public secondary schools in Enugu state. The whole population was used for the study because of the manageable size of the population. There was therefore no sampling of the population. The 
instrument used for data collection was a 24-item questionnaire titled Questionnaire on Administrative Capacity Building Development Needs of Principals in Enugu State (QACBNP). The QACBNP has three clusters and was structured on response pattern of Very Much Needed (VMN), Much Needed (MN), Little Needed (LN), Very Little Needed (VLN). Cluster A dealt with administrative capacity building needs of principals in student personnel administration. Cluster B dealt with administrative capacity building needs of principals in financial administration, and cluster $\mathrm{C}$ dealt with administrative capacity building needs of principals in school-community relations management. The instrument was face validated by three experts, two from Educational Administration and Planning, and one from Measurement and Evaluation, all from Faculty of Education, University of Nigeria, Nsukka. The validated version of the instrument was trial tested to ascertain the internal consistency reliability using Cronbach Alpha method. The reliability coefficient estimates obtained were: 0.09 for administrative capacity building needed in student personal administration, 0.78 for administrative capacity building needed in financial management, and 0.81 for administrative capacity building needed in school-community relations management. The instrument was administered to the respondents by six research assistants, who were earlier briefed by the researchers on the purpose of the study and how to administer the instrument. The completed instruments were collected immediately on completion. This ensured $100 \%$ return rate. The data collected were analyzed using descriptive statistics. The z-test statistics was used in testing the hypotheses.

\section{Results}

Data were analyzed according to the research questions

\section{Research Question One}

What are the administrative capacity building needs of principals in student personnel administration?

Table 1: Mean ratings $(x)$ and standard deviations (SD) on administrative capacity building needs of principals in student personnel

\begin{tabular}{|c|l|c|c|c|c|c|c|c|c|c|}
\hline S/N & \multicolumn{1}{|c|}{ Item statement } & \multicolumn{3}{c|}{$\begin{array}{c}\text { Principals } \\
\text { x SD Dec }\end{array}$} & \multicolumn{3}{c|}{$\begin{array}{c}\text { Vice-Principals } \\
\text { x SD Dec }\end{array}$} & \multicolumn{3}{c|}{$\begin{array}{c}\text { Combined } \\
\text { x SD Dec }\end{array}$} \\
\hline 1 & $\begin{array}{l}\text { Ability to enforce disciplined } \\
\text { learning among students }\end{array}$ & 3.64 & 0.55 & VMN & 3.56 & 0.68 & VMN & 3.60 & 0.62 & VMN \\
\hline 2 & $\begin{array}{l}\text { Ability to show interest in } \\
\text { students and their activities }\end{array}$ & 3.77 & 0.44 & VMN & 3.75 & 0.67 & VMN & 3.76 & 0.55 & VMN \\
\hline 3 & $\begin{array}{l}\text { Ability to be caring and } \\
\text { corrective when dealing with } \\
\text { students }\end{array}$ & 3.62 & 0.72 & VMN & 3.54 & 0.83 & VMN & 3.58 & 0.60 & VMN \\
\hline 4 & $\begin{array}{l}\text { Ability to show interest in } \\
\text { students' welfare }\end{array}$ & 3.76 & 0.52 & VMN & 3.55 & 0.62 & VMN & 3.66 & 0.53 & VMN \\
\hline 5 & $\begin{array}{l}\text { Ability to visit students in their } \\
\text { classes to see what they are } \\
\text { doing }\end{array}$ & 3.75 & 0.60 & VMN & 3.73 & 0.68 & VMN & 3.74 & 0.64 & VMN \\
\hline 6 & $\begin{array}{l}\text { Ability to provide guidance and } \\
\text { counselling services }\end{array}$ & 3.78 & 0.48 & VMN & 3.78 & 0.68 & VMN & 3.78 & 0.49 & VMN \\
\hline 7 & $\begin{array}{l}\text { Ability to ensure safety of } \\
\text { students }\end{array}$ & 3.82 & 0.54 & VMN & 3.84 & 0.39 & VMN & 3.83 & 0.49 & VMN \\
\hline 8 & $\begin{array}{l}\text { Ability to provide } \\
\text { communication channels with } \\
\text { the students }\end{array}$ & 3.84 & 0.38 & VMN & 3.78 & 0.56 & VMN & 3.81 & 0.49 & VMN \\
\hline & \multicolumn{1}{c}{ Cluster mean } & $\mathbf{3 . 7 5}$ & $\mathbf{0 . 5 3}$ & VMN & $\mathbf{3 . 6 4}$ & $\mathbf{0 . 6 9}$ & VMN & $\mathbf{3 . 7 2}$ & $\mathbf{0 . 5 5}$ & VMN \\
\hline
\end{tabular}

Source: field work 
Key: VMN= Very Much Need, MN =Much Needed, LN= Little Needed, NN = Not Needed.

$\overline{\mathrm{x}}=$ Mean, $\mathrm{SD}=$ Standard Deviation, $\mathrm{Dec}=$ Decision

The data analysis on Table 1 indicated that principals need administrative capacity building in student personnel administration. Hence all the questionnaire items had positive responses from the respondents as each of the items had a mean score that is above the 2.50 bench mark. This implies that the principals and vice-principals in Enugu state share the view that the skills listed are important skills that principals in the state need administrative capacity building in for effective student personnel administration in their schools.

\section{Hypothesis One}

There is no significant difference between the mean ratings of principals and vice-principals of public secondary schools in Enugu state as on administrative capacity building needed by principals in student personnel administration.

To test the hypothesis, a z-test analysis was carried out using the cluster mean score and cluster mean standard deviation obtained from items 1 to 8 of the instrument. Table 2 shows the summary of the analysis.

Table 2: Summary of z-test analysis for Hypothesis one

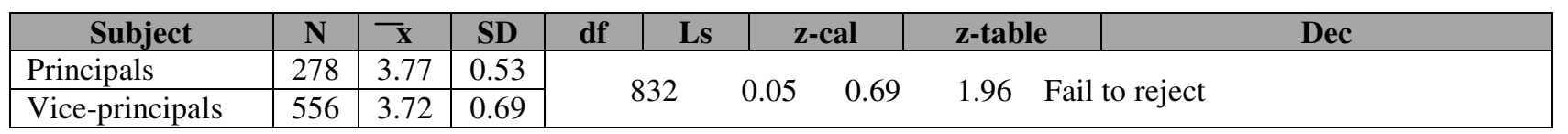

Table 2 above shows the independent z-test analysis of the mean difference in responses of principals and viceprincipals on administrative capacity building needed by principals in student personnel administration.

Looking at the table, one can see that the calculated z-value is 0.69 at 832 degree of freedom and 0.05 level of significance. Since the calculated z-value of 0.69 is less than the critical table value of 1.96 , we fail to reject the hypothesis. In other words, there is no significant difference between the opinions of principals and vice-principals on the administrative capacity building needed by principals in Enugu state in student personnel administration

\section{Research Question Two}

What are the administrative capacity building needs of principals in financial administration

Table 2: Mean rating ( $x$ ) and standard deviations (SD) on administrative capacity building needs of principals in financial administration

\begin{tabular}{|c|l|c|c|c|c|c|c|c|c|c|}
\hline $\begin{array}{c}\text { S/ } \\
\mathbf{N}\end{array}$ & \multicolumn{1}{|c|}{ Item statement } & \multicolumn{3}{c}{$\begin{array}{c}\text { Principals } \\
\text { x SD Dec }\end{array}$} & \multicolumn{3}{c|}{$\begin{array}{c}\text { Vice-Principals } \\
\text { x SD Dec }\end{array}$} & \multicolumn{4}{c|}{$\begin{array}{c}\text { Combined } \\
\text { x SD Dec }\end{array}$} \\
\hline 9 & Ability to prepare school budget & 3.74 & 0.64 & VMN & 3.76 & 0.52 & VMN & 3.75 & 0.58 & VMN \\
\hline 10 & $\begin{array}{l}\text { Ability to involve staff in budget } \\
\text { preparation }\end{array}$ & 3.66 & 0.55 & VMN & 3.68 & 0.38 & VMN & 3.67 & 0.47 & VMN \\
\hline 11 & $\begin{array}{l}\text { Ability to run the school with } \\
\text { budgetary limitations }\end{array}$ & 3.78 & 0.46 & VMN & 3.76 & 0.50 & VMN & 3.77 & 0.48 & VMN \\
\hline 12 & $\begin{array}{l}\text { Ability to explore other sources of } \\
\text { generating funds outside grants, } \\
\text { fees and levies }\end{array}$ & 3.75 & 0.58 & VMN & 3.72 & 0.56 & VMN & 3.74 & 0.57 & VMN \\
\hline 13 & $\begin{array}{l}\text { Ability to ensure that staff salaries } \\
\text { and allowance are paid as at and } \\
\text { when staff in other school are }\end{array}$ & 3.42 & 0.74 & VMN & 3.46 & 0.74 & VMN & 3.44 & 0.74 & VMN \\
\hline
\end{tabular}




\begin{tabular}{|c|l|c|c|c|c|c|c|c|c|c|}
\hline & paid & & & & & & & & & \\
\hline 14 & $\begin{array}{l}\text { Ability to make use of vouchers } \\
\text { in all financial transactions }\end{array}$ & 3.72 & 0.60 & VMN & 3.68 & 0.61 & VMN & 3.70 & 0.61 & VMN \\
\hline 15 & $\begin{array}{l}\text { Ability to give proper account of } \\
\text { school funds }\end{array}$ & 3.84 & 0.44 & VMN & 3.78 & 0.54 & VMN & 3.81 & 0.49 & VMN \\
\hline & Cluster mean & $\mathbf{3 . 7 0}$ & $\mathbf{0 . 5 8}$ & VMN & $\mathbf{3 . 6 8}$ & $\mathbf{0 . 5 5}$ & VMN & $\mathbf{3 . 6 9}$ & $\mathbf{0 . 5 7}$ & VMN \\
\hline
\end{tabular}

Source $=$ field work

Key: $\mathrm{VMN}=$ Very Much Need, MN =Much Needed, LN= Little Needed, NN = Not Needed.

$-\mathrm{x}=$ Mean, $\mathrm{SD}=$ Standard Deviation, $\mathrm{Dec}=$ Decision

The data analysis on Table 2 indicated that the principals in Enugu state need administrative capacity building in financial administration. All the questionnaire items in this cluster had positive responses from the respondents because each of the items had a mean score that is above the 2.50 bench mark. It follows then that the principals and the viceprincipals in Enugu state are of the view that the skills in the cluster are skills which the principals in the state need administrative capacity building in for effective financial administration in their schools.

\section{Hypothesis Two}

There is no significant difference between the mean ratings of principals and vice-principals of public secondary schools in Enugu state on administrative capacity building needed by principals in financial administration

To test the hypothesis, a z-test analysis was carried out using the cluster mean scores and standard deviations obtained from items 9 to 15 of the instrument. Table 2 below shows the summary of the analysis.

Table 3: Summary of z-test analysis for Hypothesis Two

\begin{tabular}{|l|c|c|c|c|c|c|c|c|}
\hline \multicolumn{1}{|c|}{ Subject } & $\mathbf{N}$ & $\mathbf{x}$ & SD & df & Ls & z-cal & z-table & Dec \\
\hline Principals & 278 & 3.70 & 0.58 & \multirow{2}{*}{832} & \multirow{2}{*}{0.05} & \multirow{2}{*}{0.48} & \multirow{2}{*}{1.96} & \multirow{2}{*}{ Accepted }
\end{tabular}

Table 3 above shows the independent z-value analysis of the mean difference in the responses of principals and vice-principals on administrative capacity building needed by principals in financial management.

Looking at the table, one can see that the calculated z-test is 0.48 at 832 degree of freedom and 0.05 level of significance. Since the calculated z-value of 0.48 is less than the critical table value of 1.96 , we fail to reject the hypothesis. In other words, there is no significant difference between the opinions of principals, and vice-principals on the administrative capacity building needed by principals in Enugu state in financial administration.

\section{Research Question Three}

What are the administrative capacity building needs of principals in school-community relations administration?

Table 4: Means (x) and standard deviations (SD) on administrative capacity building needs of principals in schoolcommunity relations administration

\begin{tabular}{|c|c|c|c|c|c|c|c|c|c|c|}
\hline $\begin{array}{l}\mathbf{S} / \\
\mathbf{N}\end{array}$ & Item statement & \multicolumn{3}{|c|}{$\begin{array}{c}\text { Principals } \\
\text { x SD Dec }\end{array}$} & \multicolumn{3}{|c|}{$\begin{array}{c}\text { Vice-Principals } \\
\text { x SD Dec } \\
\end{array}$} & \multicolumn{3}{|c|}{$\begin{array}{l}\text { Combined } \\
\text { x SD Dec }\end{array}$} \\
\hline 16 & $\begin{array}{l}\text { Ability to create good public } \\
\text { relations image among staff and } \\
\text { students }\end{array}$ & 3.46 & 0.67 & $\mathrm{MN}$ & 3.44 & 0.66 & $\mathrm{MN}$ & 3.45 & 0.67 & $\mathrm{MN}$ \\
\hline
\end{tabular}




\begin{tabular}{|c|c|c|c|c|c|c|c|c|c|c|}
\hline 17 & $\begin{array}{l}\text { Ability to create good public } \\
\text { relations image among the people } \\
\text { of the community }\end{array}$ & 3.68 & 0.53 & VMN & 3.58 & 0.72 & VMN & 3.63 & 0.63 & VMN \\
\hline 18 & $\begin{array}{l}\text { Ability to create good public } \\
\text { relations image among their } \\
\text { colleagues and the Schools } \\
\text { Management Board }\end{array}$ & 3.46 & 0.72 & MN & 3.48 & 0.63 & MN & 3.47 & 0.68 & $\mathrm{MN}$ \\
\hline 19 & $\begin{array}{l}\text { Ability to have an understanding } \\
\text { of the social life of the local } \\
\text { communities }\end{array}$ & 3.24 & 0.72 & MN & 3.18 & 0.70 & MN & 3.21 & 0.71 & MN \\
\hline 20 & $\begin{array}{l}\text { Ability to organize PTA and Board } \\
\text { of Governors meetings regularly }\end{array}$ & 3.54 & 0.78 & VMN & 3.46 & 0.68 & MN & 3.50 & 0.73 & VMN \\
\hline 21 & $\begin{array}{l}\text { Ability to allow the local } \\
\text { communities to use school } \\
\text { facilities for social activities }\end{array}$ & 3.68 & 0.33 & VMN & 3.72 & 0.58 & VMN & 3.70 & 0.46 & VMN \\
\hline 22 & $\begin{array}{l}\text { Ability to involve the } \\
\text { community in the } \\
\text { administration of the school }\end{array}$ & 3.78 & 0.66 & VMN & 3.78 & 0.64 & VMN & 3.78 & 0.65 & VMN \\
\hline 23 & $\begin{array}{l}\text { Ability to encourage } \\
\text { healthy communication between } \\
\text { the school and the community }\end{array}$ & 3.76 & 0.48 & VMN & 3.75 & 0.54 & VMN & 3.76 & 0.51 & VMN \\
\hline 24 & $\begin{array}{l}\text { Ability to encourage } \\
\text { school participation in } \\
\text { community's social activities }\end{array}$ & 3.47 & 0.68 & MN & 3.51 & 0.62 & VMN & 3.49 & 0.65 & $\mathrm{MN}$ \\
\hline & Cluster mean & 3.66 & 0.62 & VMN & 3.54 & 0.64 & VMN & 3.60 & 0.63 & VMN \\
\hline
\end{tabular}

Source: field work

Key: VMN= Very Much Need, MN =Much Needed, LN= Little Needed, NN = Not Needed.

$\mathrm{x}=$ Mean, $\mathrm{SD}=$ Standard Deviation, Dec $=$ Decision

The data analysis on Table 4 indicated that principals in Enugu sate need administrative capacity building in school-community relations administration. Thus, all the questionnaire items received positive responses from the respondents as each of the items had a mean score that is above 2.50. Invariably principals and vice-principals in Enugu state believe that the skills listed are vital skills that principals in the state need administrative capacity building in for effective school-community relations administration.

\section{DISCUSSIONS}

With reference to research question one of the study which dealt with the administrative capacity building needed in student personnel administration, the principals and vice-principals are of the opinion that the principals need administrative capacity building in this administrative task area very much.

The findings agree with Ochai (2012) who observed that for the school heads to effectively harness the manpower, funds and materials resources, they require administrative capacity building which need continual development or updating. Ozigi (2007) suggested that school administrators should possess certain skills for student personnel administration, namely: ability to provide opportunity for students' character formation, ability to understand and help solve students' personal and social problems, ability to carter for the well-being of students. The findings also agree with Farant (1999) who observed that school administrators need ability to encourage students to play a role in school administration, ability to delegate responsibilities to students; other skills like providing opportunities for students to develop responsibly, ability to ensure effective implementation of good instructional programme, ability to ensure that 
teaching and learning takes place. From the findings one can deduce that principals in Enugu state need administrative capacity building in student personnel administration.

With reference to research question two of the study which dealt with the professional skills development needed by principals in financial administration, the principals and the vice-principals are of the opinion that the principals need ability to: prepare school budget, ability to run the school within budgeting limitations, ability to explore other sources of generating funds, ability to ensure payment of salaries and allowances as at and when due, ability to make use of vouchers, among others.

The findings agree with Ochai (2012) who observed that for the school heads to effectively harness the manpower, funds, and material resources, they require professional skills which need continual development or updating. The findings agree with Federal Republic of Nigeria (2004) who noted that head teachers should acquire repertoire of relevant skills and competencies in planning all facets of school administration such as student personnel administration, school-community relations administration, financial administration, among others. The findings agree with Farley (2003) that in order to contend with the new demands and challenges of increased extension and technological advancement in the world, the school heads must acquire a repertoire of competence. One can conclude from the findings that the principals in Enugu state need administrative capacity building in financial administration.

Regarding research question three, which dealt with administrative capacity building needed by principals in school community relations, the principals and vice-principals are of the view that principals need ability to: create good public relations image among staff and students, among people of the community, and among their colleagues and the supervising agency. They further opine that the principals need ability to: have an understanding of the social life of the local communities, ability to organize PTA and Board of Governors meetings very well, involve the community in the administration of the school and allow them to use school facilities for social activities, encourage healthy communication between the school and the community, and to encourage school participation in community's social activities.

These findings agree with Mbiti (2000) who noted that school administrators should possess such skills as ability to organize an annual event that will attract parents, ability to maintain cordial relationship with staff, students and the community, ability to allow the use of school facilities by the community, among others. The findings agree with Agbo (2014) that a principal needs skills in order to nurture cooperation between the staff and the communities they serve and to assess the needs and strengths of the school and the community. The findings agree with Wikipedia (2008) which identified skills required in school community administration to include: ability to be accessible to parents and members of the public, ability to be courteous to people, ability to demonstrate an active interest in the community, ability to form and co-ordinate PTA, and ability to organize the community to visit the school on special occasions. From the findings it is deduceable that the principals in Enugu state need administrative capacity building in school-community relations administration.

The principals and vice principals do not differ significantly in their opinions on the administrative capacity building needed by principals in student personnel administration, and in financial administration.

\section{CONCLUSIONS}

Based on the findings, one can deduce that in order to perform their functions effectively and efficiently, principals require a repertoire of administrative capacity building in the different task areas of school administration. In the area of student 
personnel administration, the principals need, among others, ability to: enforce disciplined learning, show interest in students' welfare, ensure safety of student. The principals also need administrative capacity building in financial administration such as ability to prepare school budget, ability to run the school within budgetary provision, and ability to make use of vouchers. The principals need administrative capacity building in school community relations administration in such areas as ability to create good public relations image among staff, among students, among people of the community, and among their colleagues. They also need administrative capacity building in ability to encourage healthy communication between the school and the community, and to encourage active community participation in school administration.

\section{RECOMMENDATIONS}

Based on the findings, the following recommendations are made

- Serving principals and vice principals should be exposed to regular conferences, seminars and workshops on administrative proficiencies for effectiveness and efficiency.

- Seminars, workshops and conference should be regularly organized for teachers on administrative proficiencies needed by school administrators

- Faculties of education and colleges of education should include in their curricula administrative capacity needs of school administrators so that early enough future administrators are introduced to administrative proficiencies needed to function effectively and efficiently.

- Workshops and seminars should be organized for newly appointed principals on administrative proficiencies needed by principals for effective school administration.

\section{REFERENCES}

1. Agbo, D.C (2014).Staff personnel management and instructional leadership of principals as predictors of classroom practices of teacher in secondary schools in South-East, Nigeria. Unpublished Ph.D Thesis, Department of Educational Foundations, University of Nigeria, Nsukka

2. Akubue, A.U. (1985). A competency-based approach to improving environmental health programme administration by secondary school teachers in Anambra State. Unpublished M.Ed project, Department of Education, University of Nigeria, Nsukka

3. Alozie, L.I (1997) In-Service education needs of secondary school teachers in Imo State Unpublished M.Ed project, Educational Foundations, Univerity of Nigeria Nsukka

4. Arubayi, B.A (2004). Principalship in Nigeria. Journal of Nigeria Educational Research Association. 6(3), 44-49.

5. Blasé. J\& Blasé. J. (2001). Empowering teachers. (2 ${ }^{\text {nd }}$ ed). California: Corwin Press.

6. Chang, J.(n.d). Instructional leadership in a pacific context. Retrieved from http://peoplelearnhomestead.com/principalinstructionleader.htm.

7. Eleanor, C.P (2001). Educational planning guides, teaching important ingredients. Retrieved from www.goggle.com.

8. Farley. K (2003). Does science teachers demographic affect their in-service needs. Faragan@yahoo.com.

9. Farrant, J.S (2002). Principles and practices of education. Hongkong: Shelk Wali Tong Practicing Press L.T.D. 
10. Federal Republic of Nigeria (2004). National policy on education. Abuja: NERDC.

11. Igwe, S.O (2006). Professional handbook for teachers. Owerri: New African Publishing Company.

12. Nwandu, F.C, Ani, N.R \& Agbo, O.G. (1999). Principles of management. Enugu: Future Tech Publishers.

13. Ochai, J. (2012). An analysis of teachers' quality in selected primary schools in Central Equatorial, South Sudan. Kampala International University Journal of Education, 5(1), 1-13.

14. Ogbonnaya, N.O (2004). Nature and scope of educational administration. In T.O. Mgbodile (Ed) Fundamentals of educational administration and planning. Enugu: Magnet Business Enterprises.

15. Ogunsaju, S (2006). Educational supervision: Perspectives and practices in Nigeria. Ileife: University of Ife Press.

16. Omsteal, M.S (2008). Teaching principles. London: Micks Press Ltd.

17. Osinem, E.C \& Nwoji, U.S (2005). Students' industrial work experience in Nigeria: Concepts, principles, and practices. Enugu: Cheston Agency Ltd.

18. Peretemode, V.F (1996). Introduction to educational administration, planning, and supervision. Lagos: Joja Educational Publishers.

19. Peretemode, V.F (2007). Human resource management. Lagos: Onosomgbo and Oginaka Publishers Ltd.

20. United Nations Development Programme (UNDP) (1991). A strategy for water sector capacity building in delft. Netherlands UNDP Briefing Paper/Report. Rome: FAO. 